\title{
"De-mockery-cy" and the Discourse of Human Rights in Ngugi wa Thiong'o's Wizard of the Crow
}

\author{
Mustapha Bala Ruma
}

Wizard of the Crow (2007) is important in Ngugi's oeuvre because it signifies a departure from his earlier political positions. Not only did the novel come out after about two decades of inactivity in his novelistic production since Matigari (1988), it was also initially composed in Gikuyu as Murogi wa Kagogo twenty years after Ngugi said his famed "farewell to English." This sprawling 776-page magnum opus (published in Gikuyu in three installments totaling 892 pages) is probably the longest piece of prose in sub-Saharan Africa to be composed and published in an indigenous language.

\section{Introduction}

Even though the poetic medium of the novel is a European invention of the eighteenth century ${ }^{1}$, its appropriation by modern African writers is stupendous. The novel, more than drama and poetry, has come to be the most pervasive medium employed by African writers to interrogate, probe, question, and criticize the social, political, economic, and religious (mis) deeds of people. Ngugi, in particular, has used the novel to explore the problems of his native Kenyan society in particular and the African society in general. In virtually all his novels (A Grain of Wheat, 1967; Petals of Blood, 1977; Devil on the Cross, 1982; Matigari, 1988) the concern with the condition of the ordinary people is a visible textual presence. But nowhere is this concern more poignant albeit treated in a humorous manner than in Wizard of the Crow. In Wizard of the Crow the novelist is a spokesman for the weak and the oppressed; the voice of the voiceless and more importantly a provocateur for change. As Ngugi himself has noted in an address at the 2012 
Southeast Asian Review of English, 52.1(2014/2015): 99-121.

"Sunday Times Literary Awards", in fighting for democratic and civic rights, "the artist is on the side of all the forces in society that struggle to have their voices heard" (http://www.booksalive.co.za). Consequently, the artist nay writer becomes the conscience of his society as well as a catalyst for change. S/he becomes a pillar of resistance and hope propelled by an ardent desire to tell the truth about his society. As pointed out by Lyotard "the intellectuals must" at all times "try to be the salt of truth in the wound of alienation" (44). Similarly, Noam Chomsky has aptly noted that the role of the writer as "a moral agent is to try to bring the truth about matters of human significance to an audience that can do something about them" (56). Indeed Ngugi has in this novel fictionally painted a picture that is perhaps too real about the political situation of most postcolonial African nations. Unarguably, the story in this novel is packaged in an idiom that can be easily grasped by the reader, especially in Africa where freedom and democratic choice are brutally denied to the citizens by kleptomaniacal leaders bent on staying in power at all costs.

Perhaps what is unique about this novel is the pessimistic vision contained within its narrative structure. Though the revolutionary zeal for which Ngugi is traditionally known is very perceptible throughout the text, there is a near total absence of hope for positive change in the lives of the ordinary citizens of the fictional Free Republic of Aburiria. As a matter of fact Wizard of the Crow is an attempt at epic scale representation of a dystopian land and the manifest failure of its citizens to overcome a dictatorial regime that is unscrupulously ruining their present as well as their future. Hence in spite of the staunch struggles waged surreptitiously as well as blatantly against the oppressive regime of the Ruler by the "Movement for the Voice of the People", the end result is a pallid failure. On this score, the ensuing change of leadership at the end of the novel symbolizes a shattering of hopes. Indeed the coup that saw the execution of the Ruler becomes a sort of semantic graphing of hopelessness because power only changes hands 
Southeast Asian Review of English, 52.1(2014/2015): 99-121.

from one dictator (the Ruler) to another (Tajirika). As a matter of fact upon seizing power Tajirika formally announces that Aburiria now has a new ruler in the person of "Emperor Titus Flavius Vespasianus Whitehead" (WoC 753). If the former ruler is addressed as "His Mighty Excellency", Tajirika is henceforth to be addressed as "His Imperial Majesty". Aburiria has come full cycle: it starts with a dictator and ends with an emperor.

\section{The Concept of Democracy in Wizard of the Crow.}

Agnes Heller traces the origins of modern democracy to the Biblical story of Moses, his people, and the Pharaoh. She points out that the liberation of the Jews from "Egyptian slavery" marks the beginning of "the narrative of liberation" that culminates into modern democracy (259). Over the years as humanity developed from one historical stage to another, this Biblical story becomes an inspiration for people to agitate against tyranny and oppression of any kind. Across the globe, people demanded for a voice in how they are to be ruled and governed. The high point of this agitation was the French Revolution that saw the epochal termination of tyrannical monarchical rule in France. The success of this revolution produced a domino effect all over Europe in the eighteenth century. Consequently, the story of democracy became a part of the telos of human progress that was eventually consolidated during the period of European Enlightenment. Indeed the repercussion of this "Enlightenment project" can also be seen in the recent events that followed the collapse of the Soviet Union and the attendant atomization of the Eastern European nations. Thus, as seen above, democracy has arguably always been a historical byproduct of human struggle.

Democracy is a contentious concept owing to the fluidity and flexibility of its principles. For example, even though both the Presidential as well as the Parliamentary systems of government are democracies there are considerable variations in their operating principles. This lack of uniformity has drawn the attention of several scholars to the limitations of democracy. For 
Southeast Asian Review of English, 52.1(2014/2015): 99-121.

example, Slovaj Zizek has strongly denounced the concept of democracy seeing it as an empty gesture addressed to disembodied subjects. He equally sees it as essentially "antihumanistic" because it is not "made to the measure of (concrete, actual) men," but to that of a "formal, heartless abstraction" (Looking Awry 163). He equally see elections as periodic charades meant to subdue the populace through a clever masking of democracy's undersides. Hence he faulted the classical definition of democracy as a government of the people, for the people, and by the people themselves. For him democracy is a travesty because it is anchored on the understanding that "whatever electoral manipulation takes place, every political agent will unconditionally respect the results" (The Universal Exception 53). He forcefully argues that in today's world, democracy should be totally distrusted because "it is the main enemy of emancipatory politics" (Contingency, Hegemony, Universality: Contemporary Dialogues 124, cited in Vighi 326). Jacques Derrida also echoes similar sentiments about democracy. For example in an elegant formulation, he sees democracy as a fiction as well as a contraption created and forced on the people by fiat. Derrida thus signals his discussion about democracy in Rouges in the following manner:

To speak democratically of democracy, it would be necessary, through some circular performativity and through the political violence of some enforcing rhetoric, some force of law, to impose a meaning on the word democratic and thus produce a consensus that one pretends, by fiction, to be established and accepted---or at the very least possible and necessary: on the horizon. (original italics 73)

Continuing his attack Derrida further cautions that democracy as a concept as well as a practice is hollow, empty, and vacuous because it is "improper, mutable, elusive, and undecidable" and hence incapable of meeting even its own requirements (Rouges 113). Elsewhere he deploys his rhetorical skills in further unmasking the artificiality of democracy (Spectres 64). He thus describes democracy as nothing more than a promise that can only obtain 
Southeast Asian Review of English, 52.1(2014/2015): 99-121.

in "a diastema i.e. a failure, disjunction, disadjustement." Thus, for him there is no democracy but endless expectations (Rouges 86). In the same vein, Alain Badiou in The Meaning of Sarkozy (2009) encoded his objection to democracy by exposing its manipulative absurdity. He thus emphatically faulted its claims to fairness and representativeness through 'majoritarian' franchise by declaring that there is nothing sacred or "innocent" about "democratic majorities" (32). He thus sees no reason for people to "bow down to the stupidity of numbers" (ibid).

However, in spite of the forgoing arguments, there is no denying the fact that democracy as a system of government is a living reality despite its imperfections. In other words, keeping the foregoing objections aside, we can still venture to argue that democracy is a government with the consent of the governed. This presupposes that people living in a democracy shall be entitled to have their voices heard by those ruling them directly through peaceful gatherings, demonstrations, assemblies, etc. or indirectly by the use of their representatives in the parliament. The absence of either of these two conditions will turn democracy into its opposite, i.e. a dictatorship. Thus, it is practically conceivable that situations may arise in which an elected democratic government will gradually, due to a long stint in power, transmute into a dictatorship. In such situations the citizens will be denied both their civic as well as democratic rights with impunity. Dissenting voices will be hunted down to be imprisoned, tortured, or killed. Consequently, fear will become the ultimate ruling principle in such republics.

This is the situation we are confronted with in the Free Republic of Aburiria. Even though the "Second Ruler of the Free Republic of Aburiria" inherits the mantle of leadership in a smooth transition as a result of the death of the octogenarian first leader, he has over the years morphs into a dreaded dictator because, "he had sat on the throne so long that even he could not remember when his reign began" (WoC 5). This longevity on the throne has as a consequence transformed the Ruler into a megalothymic ruler that dementially sees himself as an extension of 
Southeast Asian Review of English, 52.1(2014/2015): 99-121.

the state. Hence any reference to the state, whether literally or metaphorically, becomes coterminous with a reference to him. Indeed, when one of his ministers makes the mistake of separating the Aburirian nation from the Ruler, he instantly draws the ire of "His Mighty Excellency." The minister in question is Silver Sikiokuu, the "Minister of State in the Ruler's Office". Because of the elongation of his ears as a result of a corrective surgery he undergoes in France, he "was made Minister of State in charge of spying on the citizenry" (WoC 14).

Earlier in the novel we are introduced to a disturbance that takes place at the venue of a meeting between the Ruler's representatives and the "Global Bank Mission" which is in Eldares (the capital city of Aburiria) to discuss the possibility of giving a loan to the Ruler's government to execute "the proposed national project of a palace aspiring to Heaven's gate" (WoC 48) that is grandly named as "The Marching to Heaven Project". The ordinary citizens of Aburiria having learned about the arrival of the "Global Bank Mission" decide to converge on Paradise Hotel, the venue of the meeting, so as to share in the largesse that the bank is sure to bring especially for the poor. As the omniscient narrator tells us:

The rumor circulating in the country was that the delegates might actually, be bringing a lot of cash to give to the poor; after all, it was not called the Global Bank for nothing. (WoC 73)

However, as the meeting progresses, it becomes apparently clear to the people that the bank has nothing for them. They start shouting obscenities denouncing both the bank and the project. This embarrassing moment instantly triggers a violent reaction from the police who descend on the poor with maximum ferocity under the glare of the "cameras of the foreign journalists" that are there to cover the event (WoC 74). It is in trying to exonerate himself from this apparent failure of the police that Minister Sikiokuu blunders by promising to thoroughly fish 
Southeast Asian Review of English, 52.1(2014/2015): 99-121.

out and bring to the Ruler "all the enemies of you, Our Ruler, and of the country"(WoC 135).As soon as the Minister finishes talking, the Ruler retorts angrily at him:

"You little cunt of a man!...Why do you go on and on about my enemies and those of the Country? Is there a distinction between me and the Country?"(WoC 136)

By merging his personality with that of the Aburirian nation, the Ruler has become an anthropomorphic figure par excellence. The nation itself is now seen in the Ruler's eyes as a conquered territory and as such its future can be mortgaged to the Global Bank as he deems fit. In a brazen display of this conquering mentality, the Ruler bluntly declares that "Every Aburirian child knows that I am the Country and the Country is Me, which means that this Excellency, this Country, and this Nation are like the mystery of Three in One and One in Three creating the Perfect One" (original italics, WoC 698). As Ngugi himself has aptly pointed out in his 2009 book Something Torn and New the dilemma of the African middle/ruling class in contrast to their counterparts in Europe is that "It was a class with no capital, no inventors among its members, no new worlds to conquer and rob-----only a world in which to beg and a nation to rob" (81). Indeed, the events that unfold in Wizard of the Crow are a living testimony to the rapacious nature of the African middle class.

In this fictional African republic, the ruling class constantly thwarts the will and wish of the people. For example, whereas the people are hungry for democracy, the Ruler sadistically refuses to grant their demands. Instead he turns democracy into what Zizek has called a "floating signifier" whose meaning and boundaries are fixed by the authoritative voice of the Ruler (Looking Awry 128-129). For instance, even though the Ruler as a result of extreme pressure from his Western allies (the USA, France and Germany) has agreed to allow for multi-party politics to be operational in the Republic in what he terms as "Baby D"(WoC 698), he 
Southeast Asian Review of English, 52.1(2014/2015): 99-121.

nonetheless hijacks the whole process by declaring himself as "the nominal head of all (the) political parties"(WoC 699). A logical follow up to this is that whichever party wins the election will have the Ruler as its de jure leader. As a result of this the Aburirian nation is turned into what Lyotard has called a "unipolar state" (xx), a situation whereby "all possibilities" are deemed "as representable for and by the state (original italics). By so doing, he deprecates the concept and idea of democracy into a laughable project. As a matter of fact, democracy in Wizard of the Crow is nothing more than what Derrida has called in the Spectres of Marx "an infinite promise" (65) without end. It is also the Derridean "conceptual surplus" (cited in De Man 3) which means is neither here nor there. In fact, what we have in Wizard of the Crow is not a democracy but "a democracy to come" (Spectres 64); a yet-to-come event; an unfulfilled promise and desire; a mockery.

This absence of a free democratic space in the Ruler's Aburiria triggers the emergence of the "Movement for the Voice of the People" a clandestine socio-political group headed by Grace Nyawira. The raison d'être for establishing this group is "to champion democracy and denounce dictatorship" (WoC 246). As a matter of fact, this group poses the most formidable existential challenge to the Ruler's government throughout the novel for several reasons. For example, though the government knows that the group exists, it cannot say for sure where it is or who its members are. Even when Nyawira is pinpointed as one of its leaders, it becomes a herculean task for the police and the M5, the Ruler's secret police, to track let alone arrest her. Throughout the text this group doggedly fights the Ruler's government sometimes symbolically using "plastic snakes and leaflets" (WoC 136) to disperse gatherings organized by the government and at other times practically embarrassing the government through a bizarre dance in front of its august visitors as it happens at the site of the dedication to the "Marching to Heaven Project":

The women, Nyawira now among them, walked in pairs into the 
arena from every direction, dressed no different from the crowd. Nothing in fact stood out except their disciplined formations and dignified entrance. They were silent, somber, as if in a funeral procession. "And then, just as planned," Nyawira told Kamiti, "all of us in the arena suddenly faced the people, our backs turned to the platform. All together we lifted our skirts and exposed our butts to those on the platform, and squatted as if about to shit en masse in the arena.... There were two or three women who forgot that this was only a simulation...they urinated and farted loudly..."(WoC 250)

Soon after this episode Nyawira is declared wanted by the government and the Movement itself becomes banned. This however only emboldens Nyawira and her comrades in the Movement. They shift underground to strategize on how best to counter the moves of the Ruler's government. Consequently, they make their presence felt at every gathering organized by the government. Indeed they become the only opposition to the government. Accordingly, in the absence of formidable opposition political parties, the Movement becomes the rallying point for dissenting voices within the Aburirian body politic. In this regard the marginalized from among the peasants, students, and women in particular gravitates toward its call and cause. In fact even the little concessions (like the birth of "Baby D") allowed by the Ruler are a result of the agitation of this group. The ability of the group to mobilize people, sometimes at short notice, is tremendous. Though they fail to bring any real change to Aburiria in terms of political and democratic liberation, their efforts are nonetheless commendable. For instance, it is their strategy which enables Vinjinia to locate her husband Tajirika when he is arrested by the M5 on the orders of Minister Sikiokuu.

In yet another place we see how a branch of the group known as the "people's court" (WoC 435) consisting of mainly women, acting on a complaint lodge by Vinjinia, forces Tajirika to desist from any further acts of violence against her. They threaten to mercilessly deal with him were he to raise a finger again towards her. In this respect, they further threaten to cut off his 
penis using a machete was he to violate this injunction. And on the account of the matter before the "court" he is found guilty as charged and instantly punished by the judge: "You are sentenced to receive as many blows as you rained on your wife." Even as the women pummeled him, his eyes were focused on the machete. His pain was dull; his stare was blank" (WoC 439). This brazen display of force against Tajirika by the women reaches the ears of the Ruler in far away USA. To say that he is deeply embarrassed by the situation is an obvious understatement. The urgency with which he instructs Sikiokuu to fish out both Nyawira and the members of the "people's court" before he returns from the USA is a pointer to the magnitude of the embarrassment. Thus the order issued to Sikiokuu by the Ruler is clear and unmistakable: "I want the leaders of rebellious youth and women to be crushed like ants" (WoC 558).

\section{Human rights and the Iconography of Dictatorship in Wizard of the Crow.}

It is pertinent to stress from the beginning that 'human rights' is a notoriously complicated and contested concept in political and social discourse. In this regard, some scholars have even questioned the possibility of the existence of human rights in particular and natural rights in general. For example, Edmund Burke, Jeremy Bentham, and Alasdair MacIntyre have separately denounced the existence of human or natural rights, seeing the concepts variously as "a monstrous fiction" (Burke); "a simple nonsense" (Bentham); and as "figments of the imagination" in several respects similar to "witches and unicorns" (MacIntyre) (cited in Forsythe 37). Yet other scholars such as Richard Falk see the discourse of human rights as a purely Western invention couched in a language of universality. In this regards Falk says:

The evolution of human rights as a self-conscious tradition was principally associated with Western thought and practice, although formulated as if metaphysically grounded on principles of universal validity. (49) 
Southeast Asian Review of English, 52.1(2014/2015): 99-121.

However, in spite of these rhetorical distanciations, it is my contention that the existence of some human desires that are universally shared by people irrespective of their origin, race, or place of domicile is undeniable. That is to say there are some core human values that are cherished by all people at all time regardless of their gender, race, religion, region, etc. Such values include but are not limited to freedom, equality, justice, and dignity. It is these core human values that principally constitute what has come to be human rights. As Forsyth rightly points out: "Human rights are widely considered to be those fundamental moral rights of the person that are necessary for a life with human dignity" (3). These rights are inalienable and as such must be guaranteed and respected by co-individual citizens as well as by constituted authorities for the smooth conduct of communities. It is a moot point, in my view, whether these rights are recognized as natural rights or simply as human rights; what is important is that they have to be respected especially by constituted authorities that hold 'the power of life and death' in their hands.

Certainly, it is important to safeguard human rights because it is a means of increasing world security. As John Locke has rightly pointed out the main reason for the existence of public authority is to safeguard and "secure these rights in legal practice" (cited in Forsyth 39). Needless to say, human rights discourse has come to dominate international politics as a result of the events of the First and Second World Wars. The aftermath of the two wars created a political consciousness in the mind of the international community to monitor human rights violation in all countries. In fact it is difficult to disagree with Anthony Julius who aptly noted that human rights movement "is the new secular religion of our time."

Since, as pointed out above, human rights are people's rights, it logically follows that there is a direct connection between liberal democracy and human rights. As a matter of fact, one of the reasons for establishing liberal democratic states all over the world is to safeguard 
Southeast Asian Review of English, 52.1(2014/2015): 99-121.

universal and natural human rights of the citizens. As noted by Bridges liberal democracies are those states in which "all individuals are treated equally" without prejudice to their "religious beliefs, ethnicity, race, social class or nationality" (1). In other words in a liberal democracy the rights of the people should be assured and secured in both public and private domains. Indeed it is important to safeguard human rights in the public sphere because it is the space in which "the metaphysical drama of human life" is articulated (Bridges 121). Moreover, it is even more important for this power of protection by the state to be extended to the private sphere because of its inherent seclusion. As Lyotard has persuasively pointed out, the private sphere is the place that tragedy occurs precisely because "it is the shadowy space...that escapes the light of public speech" (101). In the discussion that follows, we will briefly take a look at how human rights are violated in both the public as well as the private spheres in the fictional African "Free Republic of Aburiria".

If the principles of democracy are distorted and manipulated by the Ruler with the sole aim of perpetuating himself in power, he executes that effort through the total denial of the fundamental human rights of the citizens. As a matter of fact, the Ruler is a horrible combination of the Machiavellian prince and the Shakespearean Iago with a Freudian ego. He thus disdains challenges and finds it particularly important to stifle all voices of opposition to his rule. One of the ways of achieving this desire is to use terror and violence against both his friends and foes. It is with this aim in mind that the Ruler devises the best means of sustaining his oppressive rule. It is supremely pertinent to remember that human rights violation, under whatever guise, is a moral and reprehensible evil. As a matter of fact scholars such as Susan Neiman in her book Evil in Modern Thought: An Alternative History of Philosophy has argued that there is a sharp distinction between natural and moral evil, "between suffering caused by a natural disaster such as an earthquake, and suffering caused by acts of human cruelty" (cited in Billias 68-69). 
Whereas the former is a natural evil, the latter is a moral evil that is preventable. More importantly moral evils such as human rights violation occurs according to Neiman "because of decisions that people make, and that could be made differently" (ibid). It is noteworthy that human rights violations by governments against their citizens are never haphazard and uncoordinated but are most often a product of long-time planning and execution. In fact it is difficult to separate governance with violence. For example, Zizek has aptly observed that political power most often depends on an "obscene stain of violence" (The Parallax View 338). He however draws a distinction between what he calls "bad violence" and "ethical violence". In this respect, bad violence is a kind of terror that is used for its own sake as we see in the "Ruler's Republic". Ethical violence (or "good terror") on the other hand is a benevolent violence that aims at converting the people to the good cause.

In addition, it stands to reason that there is a transferential relationship between human rights violation and dictatorship. It is therefore not surprising that violence and human rights abuses are commonplace in the tapestry of Wizard of the Crow. As a matter of fact, human rights violation is the thread that stitches the narrative together in this monumental satiric novel. Interestingly, it is not only the Ruler that is guilty of human rights abuses in the novel. Indeed human rights violation in the novel can be seen in both the public as well as the private spheres; by the government and its agents as well as by individual citizens and groups.

\section{A Chronicle of human rights violations in Wizard of the Crow.}

The first person to suffer gross human rights violation in the hands of the Ruler is his wife Rachael. She courts the Ruler's anger when she advises him to be circumspect in his sexual infidelity. She particularly cautions him to stay away from "schoolgirls who, rumors claimed, were often invited to the State House to make his bed" (WoC 6). She reasons that as the acclaimed "Father of the Nation" it is grossly improper for him to be involved with girls young 
enough to be his grand-daughters. Of course the Ruler does not like this unsolicited advice from his wife and there and then decides to punish her by consigning her to perpetual solitary confinement in "a seven-acre prison... surrounded with a stone wall and an electric fence" (WoC 7-9). In this prison everything including the movement of time is subjected to a uniform immobility and hence frozen and static at the beckoning of the Ruler. Of course it is general knowledge that dictators of any kind are always wary of progress and progressive tendencies especially those of temporal dimensions like the passage of time, because it is a sign for their mortality and vulnerability. "Time", in the words of Arthur Schopenhauer "is that in which all things pass away" (19) and dictators are morbidly afraid of the passage of time because they have no effective control over its cause and effects. Nevertheless in Wizard of the Crow we are confronted with a demiurgic ruler that attempts to control the movement of time as a means of punishing his wife. As we are told in the novel he puts Rachael in the solitary confinement in order to demonstrate to her "that he, the Ruler, had power, real power over everything including...yes...Time" (WoC 7). Thus Rachael is detained in this "open-prison" until her eventual death in a mysterious fire.

Titus Tajirika, the owner of Eldares Modern Construction and Real Estate and Chairman of the "Marching to Heaven Project", is picked by the M5 operatives in the wee hours of the night on the instruction of Silver Sikiokuu, Minister in the Ruler's office. He is wanted for questioning because his ester while company secretary, Grace Nyawira, has been identified as one of the members of the "Movement for the Voice of the People." His wealth and position does not in any way shield him from the wrath of the agents of the Ruler's government.

As is the practice in dictatorships, the "plain cloth" security operatives arrest him "at midnight" in front of his wife Vinjinia: "They threw him into the back of a Land Rover like a log of wood, ignoring the entreaties of Vinjinia. They said not a word," and "did not identify 
Southeast Asian Review of English, 52.1(2014/2015): 99-121.

themselves" (WoC 301). Thereafter, Tajirika is held incommunicado for several days. In the course of his detention and interrogation he is severely beaten and brutalized by the police. For example, in one of such scenes a graphic picture of how he is brutalized is given: "He had not expected the blow, and so when it came, a full and forceful slap across his face, Tajirika saw a thousand stars in the darkness of his mind" (WoC 329).

Again and again we see this scenario replaying itself until he regains his freedom by taking the whole detention camp, officers and men inclusive, hostage at "shit point"(WoC 392). He does this by getting hold of the over-brimming bucket he uses as his toilet in his detention cell. He thereafter claims that he has the HIV virus and will not hesitate to splash the content of the overflowing bucket on any person that comes near him. Thus holding his bucket he asks to be taken to Minister Sikiokuu. It is indeed a comical scene as we are told, "[o]utside, Tajirika ordered the men to lead the way and warned them once again no to do anything foolish, following closely behind with the bucket of his own shit dangling between his legs" (WoC 387). Soon after, the Camp Chief telephones Sikiokuu and informs him that there "is a prisoner here who has virtually taken over the camp with a bucket of shit" (WoC 388). Tajirika is however released after extracting a forced confession from him that indirectly implicates Markus Machokali the Aburirian Foreign Minister and Silver Sikiokuu's rival in the Ruler's government of involvement with the "queuing mania"(393).

Tajirika's wife Vinjinia is also picked by Kaniuru "the Deputy Chairman of the Marching to Heaven Project" and the Chairman of "the Commission of Inquiry into the Queuing Mania" (WoC 260). In typical fashion of what Derrida aptly calls a coup de force, Vinjinia is abducted and psychologically tortured by Kaniuru and his men in her "Golden Heights" residence after sunset: "she was suddenly grabbed by people she had not seen approach and was dragged into a vehicle that drove off immediately" (WoC 451). After her arrest she is taken to the "Red River" 
Southeast Asian Review of English, 52.1(2014/2015): 99-121.

and threatened to be thrown into it unless she reveals the identities of the women that helped her to force Sikiokuu to publicly admit that they are holding Tajirika. Even though she is in their hands for only a couple of hours, this harrowing experience nonetheless leaves an indelible mark on her psyche.

The profundity of state violence and intimidation in the Free Republic of Aburiria can be seen in the fact that even serving ministers are prone to have their human rights violated. For instance, Foreign Minister Markus Machokali disappears soon after the American ambassador to Aburiria Mr Gabriel Gemstone suggests that the Ruler vacates the throne for young people like him (WoC 583). Instantly he is marked for elimination by the Ruler. "It was the Eldares Times that broke the news about Machokali" with the headline: "MACHOKALI MISSING" (bold type original, WoC 604). Thereafter people in Aburiria become bewildered with the news:

In all Aburiria, people were asking themselves: How can a cabinet minister disappear, like a goat or a child, without a trace? A Minister for Foreign Affairs, who had so ably represented the Ruler in the courts of the great all over the world----how could he just vanish like that? WoC 605)

And vanish he does never to be seen again in what the Ruler's government describes as "SelfInduced-Disappearance [SID]" (WoC 713).

Julius Ceaser Big Ben Mambo, Minister of Information in the Ruler's government, also suffers a similar fate with Machokali. He is arrested by the agents of the Ruler's government on a trump-up charge "of plotting against the State" (WoC 718). However the real reason behind his death is that he once had an affair with "Dr. Yunique Immaculate McKenzie, Official National Hostess" in the Ruler's State House (WoC 696). As an honorary member of the Aburirian Armed Forces, Big Ben Mambo is "arrayed before a court-martial" (718) and is subsequently found 
guilty as charged. In a compelling demonstration of the Ruler's ruthlessness Big Ben Mambo is sentenced to death by the firing squad:

It is said that as he faced the firing squad the blind-folded Julius Ceaser Big Ben Mambo found his tongue at the very last minute Crow...Protective... If... but the first bullet did not let him complete the sentence. (WoC 720)

This pattern of human rights violation becomes a recurrent leitmotif in Wizard of the Crow. Again and again we are confronted with the story of people once very close to the Ruler, suddenly disappearing without a trace from the Aburirian 'politscape'. Another example is that of Luminous Karamu-Mbu the "official loyal biographer" of the Ruler who also disappears in circumstances very similar to those of Machokali. He particularly courts the ire of the Ruler when he faithfully records the Ruler's "autoexplosion" (WoC 707), a phenomenon that sees the Ruler exploding after suffering from prolonged "Self-Induced Expansion" (SIE). As explained in the novel, 'SIE' is a situation that makes his body to awkwardly expand into a grotesque figure as a result of anger caused by his failure to secure the most sought loan for the "Marching to Heaven Project" from the Global Bank despite visiting them in New York (WoC 493,709). The Ruler has expected Karamu-Mbu to “sugarcoat reality and make it more palatable" by veiling the Ruler's failures and weaknesses in beautiful rhetoric (WoC 709).But having learned that nothing escapes the notebook of his biographer, the Ruler becomes macabrely terrified by the "the sudden realization that the loyal biographer knew too much" for his safety (WoC 709). He too therefore has to die:

Whatever the case, Luminous Karamu-Mbu, the ex-Communist born again as a loyal biographer, was never seen again, with rumors later claiming that the man had been crushed under the weight of his huge pen and notebook. (WoC 709)

It seems that there is no end in sight for human rights violation and violence in Wizard of the Crow. Violence continues even in the Imperial State of Aburiria after the ouster of the Ruler 
Southeast Asian Review of English, 52.1(2014/2015): 99-121.

in what his executioners call a "premeditated SID" (WoC 753). In a planned sweet revenge, the new ruler of Aburiria Emperor Titus Flavius Vespasianus orders his henchmen simply known as "the four spirits" (WoC 746) to kill and dump the bodies of his former torturers Njoya, Kahiga and Kaniuru in the Red River now renamed the "Imperial River" (WoC 755).

Human rights violation in the private sphere of the home also abounds in Wizard of the Crow. Reading through the text it is easy to fathom why this is so. For instance, probably taking a cue from the Ruler, wife bashing becomes the prerogative of the Aburirian men and serve as an index of their masculinity. Men in Aburiria work with the faulty assumption that they have the matrimonial right to beat their wives with impunity at the slightest provocation. This fact can be gleaned in the following exchange between Sikiokuu and Tajirika:

"When you get home...I want you to listen to Vinjinia's story...

But you must not touch her before we have investigated...this affair."

"Are you trying to tell me that I cannot beat my wife without your permission?" Tajirika asked defiantly.

"I am not asking you to retire from wife beating. How can I ask you

to give up what defines modern Aburirian manhood?" (WoC 403-404)

As a matter of fact, women in the eyes of many men in Aburiria are nothing but sexual objects and punch-bags; they can be abused by the men at will. We have already seen how the Ruler incarcerated his estranged wife Rachael under house arrest until her death. Yet another example of this human rights violation at the home front can be seen in the severe beating Vinjinia receives at the hands of her husband Tajirika (WoC 426).

It is interesting to note that it is not only the Ruler and his cohorts that are guilty of human rights violation in Aburiria. Some of the members of the "Movement for the Voice of the People" are equally guilty of this offence as we have seen earlier where a group of women manhandled Tajirika after a complaint is lodged against him by Vinjinia. The women in the name of what they 
Southeast Asian Review of English, 52.1(2014/2015): 99-121.

call "A new order of justice created by today's modern woman" (WoC 435) track and abduct

Tajirika to an unknown location where he is subjected to a severe beating:

Tajarika did not even know who touched him first or from what direction,but the next second he found himself lying flat on the floor with three women sitting on his back; one at the neck, another at the waist, and the other one at the feet. (WoC 434)

Thereafter he is subjected to a severe beating that leaves him sobbing with tears of "shame, anger, and helplessness" (WoC 440). From the foregoing it is fairly clear that modernity in Aburiria is measured by the sophistication as well as the degree of violence meted out on the weak by the strong. Indeed, it is difficult to miss the evident circularity of violence in Wizard of the Crow. As mentioned earlier, violence is the thread that stitches the narrative together in this monumental novel.

\section{Conclusion}

In Wizard of the Crow democracy qua bastion of freedom and choice is a misnomer. In reality democracy is never allowed to operate in the Free Republic of Aburiria because it is against the grand design of the Ruler. As a megalothymic dictator, his political game-plan is to perpetuate himself in power through a manipulative combination of terror and deception. Indeed, in the political landscape of Aburiria there is an enchanted chasm between what the people want and what they are allowed to have. In this regard, while they yearn for freedom and political choice, they are given blood and tears instead. Even though at some point in the narrative the Ruler is made to bow to the demands of the Western powers to introduce some political reforms such as multiparty democracy, he nonetheless hijacks the program by installing himself as the only candidate for all the political parties participating in the stage-managed election. He thus turns democracy into an illusionistic project or in Zizek's memorable phrase "a floating 
signifier." As such democracy in Wizard of the Crow is not a reality because its principles are never allowed to fully operate. Indeed, democracy in this narrative is the equivalent of the Derridean promise or to put it in another way "a democracy to come." Similarly, human rights which form the second leg of the democratic process are constantly violated with impunity in the "Free Republic" that is run with ruthless efficiency. In fact there is an infernal cycle of violence in the novel where citizens are made to disappear without a trace. Hence, the socio-political landscape of Aburiria becomes irremediably poisoned with this totalitarian violence. Consequently, Wizard of the Crow becomes a metaphorising discourse of endless disappointments. In fact the novel is a sad commentary on the political situation of most developing nations especially in Africa, Asia, and Latin America. The novel can actually be seen as a synchronic political satire of some of the most dictatorial regimes in the world. 
Southeast Asian Review of English, 52.1(2014/2015): 99-121.

\section{WORKS CITED}

Alain, Badiou. The Meaning of Sarkozy. London \& New York: Verso, 2006. Print.

Billias, Nancy (ed.). Promoting and Producing Evil. Amsterdam and New York, N.Y: Rodopi, 2010(E-Book).

Bridges, Thomas. The Culture of Citizenship: Inventing Postmodern Civic Culture. (2 ${ }^{\text {nd }}$ edition). Washington, D.C.: The Council for Research in Value and Philosophy, 1997. Print.

Chomsky, Noam. Powers and Prospects: Reflections on Human Nature and Social Order. London: Pluto, 1996. Print.

De Man, Paul. Allegories of Reading: Figural Language in Rousseau, Nietzsche, Rilke, and Proust. New Haven: Yale UP, 1979. Print.

Derrida, Jacques. Spectres of Marx: The State of the Debt, the Work of Mourning, \& the New International. Peggy Kamuf (Trans.). New York and London: Routledge, 1994. Print.. - Rouges: Two Essays on Reason. Trans. Pascale-Anne Brault and Michael Naos. Stanford: Stanford UP, 2005. Print.

Falk, Richard A. Human Rights Horizons: The Pursuit of Justice in a Globalizing World. New York and London: Routledge, 2000. Print.

Forsyth, David P. Human Rights in International Relations. Cambridge: Cambridge UP, 2012. Print.

Heller, Agnes. "European master narratives about freedom.” In Gerard Delanty(Ed.). Handbook of Contemporary European Social Theory. London and New York: Routledge, 2006. Print.

Julius, Anthony. "Human rights: the new secular religion." The Guardian, Monday 19 April 2010. http://www.theguardian.com/commentisfree/2010/apr/19/human-rights-new-secularreligion Retrieved November 14, 2013. 
Southeast Asian Review of English, 52.1(2014/2015): 99-121.

Lyotard, Jean-Francois. Political Writings. Trans. Bill Readings and Kevin Paul. Minneapolis: University of Minnesota Press, 1993. Print.

Ngugi wa Thiang'o. Wizard of the Crow. Lagos: Farafina, 2007. Print.

-------------.- Something Torn and New: An African Renaissance. New York: Basic Civitas Books, 2009 (E-Book).

-----------------. “Speaking my Language.” An Address at the 2012 Sunday Times Literary Awards, June 25, 2012. http://www.booksalive.co.za/blog/2012/06/25/speaking-mylanguage- Retrived November 21, 2013.

Schopenhauer, Arthur. Complete Essays of Schopenhauer: Seven books in one Volume. T. Bailey Saunders (Trans.). New York: Willey, 1942. Print.

Vighi, Fabio. On Zizek's Dialectics: Surplus, Substraction, Sublimation. London \& New York : Continuum, 2010. Print.

Zizek, Slavoj. Looking Awry: An Introduction to Jacques Lacan through Popular Culture. Cambridge, Massachusetts: MIT Press, 1992(1995). Print. -. The Universal Exception. Rex Butler \& Scott Stephens (eds.). London \& New York: Continuum, 2006. Print. - The Parallax View. Cambridge MA and London: MIT Press, 2006. Print.

\section{Notes}

1. For a comprehensive discussion on the origin of the novel see Ian Watt's The Rise of The Novel (1957); Michael McKeon's The Origins of the English Novel 1600-1740(1987); Lennard Davis' Factual Fictions: The Origins of the English Novel (1983); J. Paul Hunter's Before Novels (1990); and Firdous Azim's The Colonial Rise of the Novel (1993). Watt for 
Southeast Asian Review of English, 52.1(2014/2015): 99-121.

instance has linked the rise of the novel in England to the increased level of literacy among the reading public in the eighteenth century, the rise of modern industrial capitalism and the spread of Protestantism. Azim on the other hand traces the origins of the novel to the philosophical and ideological debates around the status of the human individual and its relationship with language in the eighteenth century. 